\section{選択的順行性脳灌流を用いた弓部全置換術におけ る大脳白質病変のもたらす影響についての検討}

\author{
*神戸大学 心臟血管外科 \\ **同 放射線科
}

池 野友 基*, 佐々木康二**, 大山詔子*, 幸田陽次郎*, 陽川孝 樹*, 後竹康子*, 邊見宗一郎*, 中井秀 和*, 松枝 崇*, 山中勝弘*, 田中裕史*, 杉本幸司**,

大北裕*

\section{背景}

順行性脳灌流法の確立により, 近年, 弓部全置換術の成 績は著しい発展を遂げている。一方で，この 10 年の間に は胸部大動脈ステントグラフト内挿術の出現もあり, 特に ハイリスク症例を中心に魅力的な治療戦略の 1 つと考えら れるようになった。しかし，弓部全置換術，ステントグラ フト内挿術いずれの術式を用いる場合においても，周術期 脳合併症はいぜんとして弓部大動脈瘤治療の最も重大な合 併症の 1 つである.

大脳白質病変 (WMC : white matter change) は微小血 管障害を反映した加齢性変化であり，in vivo では，䯣鞘 や軸索の障害による変化であると考えられており，慢性脳 虚血モデルマウスにより再現性を持って導入されたことが 証明されている ${ }^{1)}$. 加えて近年の MRI 画像解析技術の進 歩により, WMC は, Frailtyの中核症状の 1 つである認知 機能障害との関連が示されるようになってきた2,3)．これ までに種々の WMC の評価方法が提案されてきたが，な かでも Fazekas らによって報告された Fazekas スケール は簡便かつ再現性のある評価方法として広く用いられてい る4).

今回の研究では，Fazekas スケールを用いた術前 WMC 評価が弓部全置換術の早期・長期成績に及ぼす影響につい て検討を行った。

$$
\text { 方法 }
$$

1999 年 10 月から 2016 年 12 月までに, 神戸大学心臟血

$$
\text { 第 } 48 \text { 回日本心臟血管外科学会学術総会優秀演題 }
$$

本研究において一切の利益相反や研究資金の提供はない.

None of the authors of this manuscript has any financial or personal relationship with other people or organizations that could inappropriately influence their work.
管外科で待機的に施行した弓部全置換術 449 例のうち，順 行性脳灌流以外の脳保護を用いた 40 例, 術前 MRI 画像が 得られなかった 50 例を除外した 359 例を対象とした。平 均観察期間は $4.8 \pm 3.6$ 年であった。

MRI 評価の方法として FLAIR (fluid-attenuated inversion recovery）像を用いて, Fazekas スケールにより患者 群を 3 群に分類した (Fig. 1A，B，C)。

Grade 1 (Mild)：側脳室周囲にCap を認める，あるい は深部白質に点状の高信号病変を認めるもの

Grade 2 (Moderate)：側脳室周囲にリム状の高信号病 変を認めるもの，あるいは深部白質に斑状の高信号病変を 認めるもの

Grade 3 (Severe)：深部白質に達する側脳室周囲病変や 深部白質の癒合傾向を示す高信号病変を認めるもの

検者間での䛊差を考慮して, MRI 画像の読影は心臟血 管外科医 1 名と放射線科医 1 名で全症例に対して盲検的に 行い, 重症度評価は $\kappa$ 係数 0.65 と検者間で有意に相関し, 特にSevere WMC の検出においては $\kappa$ 係数 0.86 と非常に 強い相関が認められた。

神経学的合併症の定義として, 恒久的脳障害 (PND : permanent neurological deficits）は，退院時に残存する神 経学的障害と定義され, 一過性脳障害 (TND : transient neurologic deficits) は, 覚醒遅延, 見当識障害, せん妄, 一過性片麻痺といった退院時に改善のみられる神経学的障 害と定義した。PND，TNDいずれも術後新規に発症した もののみと定義し，7名の術後回復期に生じた脳梗塞は， PND，TNDいずれからも除外した。

\section{結果}

Fazekas スケール評価により，359 例は, Mild WMC 100 例 (27.9\%), Moderate WMC 158 例 (44.0\%), Severe WMC 101 例（28.1\%）の 3 群に分けられた。術前患者背景 は Table 1 に示している. 加齢性変化を反映して, Severe WMC 群では，有意に高齢 $(p<0.001)$ かつ，有意に多く の症例で腎機能障害 $(p<0.001)$ p冠動脈病変 $(p<$ $0.001)$, 頸動脈狭窄 $(p=0.014)$ といった動脈硬化に起因 する併存疾患を抱えていた。また Severe WMC 群では, 有意に多くの症例で, MRIにて評価される以前の脳梗塞 病変を認め $(p<0.001)$, それによって生じる片麻疩など の神経学的障害も多く認められた $(p=0.005)$.

術中データを Table 2 に示した. WMC の重症度と相関 して最低鼓膜温が有意に低く $(p=0.002)$, 順行性脳灌流 時間が有意に長い $(p=0.002)$ という結果が得られた。 


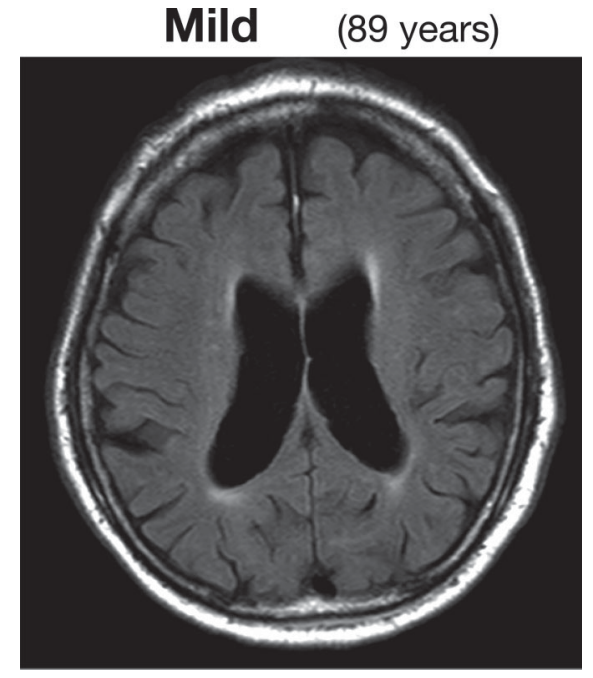

( A )

\section{Moderate (83 years)}

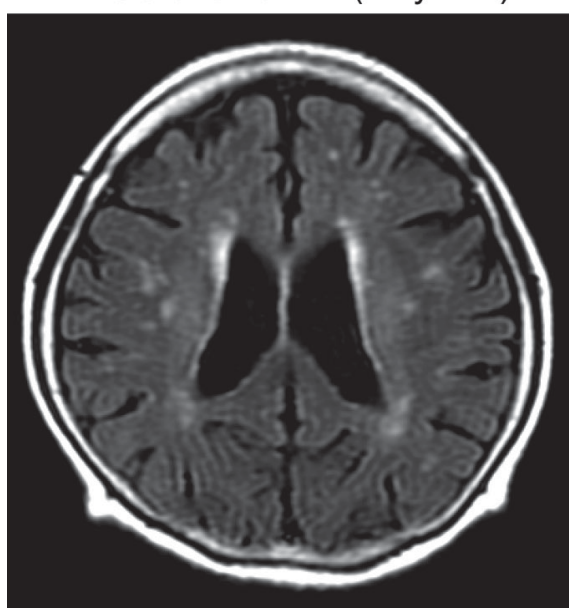

( B )

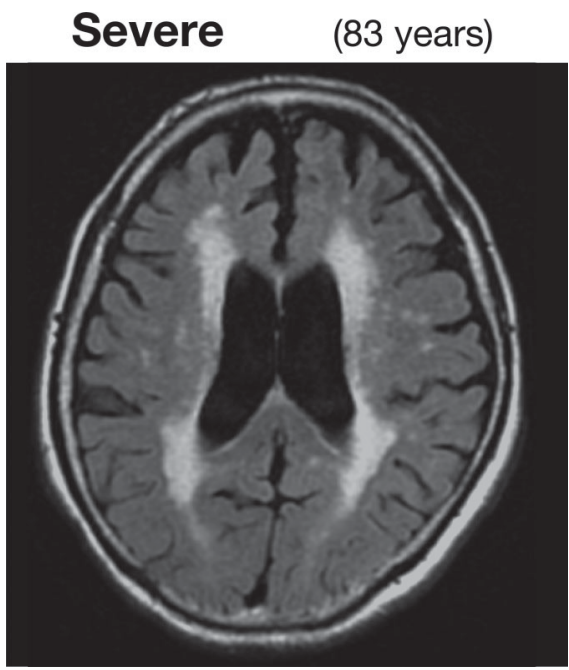

( C )

Fig. 1

Magnetic resonance images of Mild (A), Moderate (B), and Severe (C) white matter changes on the Fazekas visual scale.
30 日死亡率と院内死亡率はそれぞれ，1.4\%（5/359）， 2.8\%（10/359）であった。院内死亡の原因として, 腸管壊 死 2 例, 脳出血 1 例, 肺出血 1 例, 多臟器不全 1 例, 敗血 症 1 例, 腸管穿孔 1 例, 重症膵炎 1 例, 肺炎 2 例であっ た. Severe WMC は院内死亡の有意な危険因子としてあげ られなかったものの， 1 年死亡の有意な危険因子としてあ げられた（Mild: 5.1\%，Moderate : 5.4\%, Severe : 14.7\%, $p=0.014)$. 神経学的合併症の発生については, PND, TND はそれぞれ $2.2 \%, 7.8 \%$ で生じ, PND の発生は WMC 重症度と有意な相関を認めた (Mild: 0\%, Moderate： $1.3 \%$, Severe : $5.9 \%, p=0.004)$. 同様に, TND の発生も WMC 重症度と有意に相関した (Mild : 4.0\%, Moderate : $5.7 \%$, Severe : $14.9 \%, p=0.004)$. 術後心房細動の発生を 除き (Mild : 24.0\%, Moderate : $31.7 \%$, Severe 37.6\%, $p=0.037$ ), 深部創感染, 肺炎, 嗄声, 長期人工呼吸器管理, 気管切 開，腎不全といったその他の術後合併症の発生については 有意差を認めなかった。

PND の発生に対する単変量解析では, atherothrombotic aorta, Severe WMC，人工心肺時間が有意な危険因子とし てあげられ，多変量解析でも， atherothrombotic aorta（才 ッズ比 7.56, 95\% 信頼区間 1.37-38.6, $p=0.023$ ), Severe WMC (オッズ比 7.56, 95\% 信頼区間 1.54-55.6, $p=0.012$ ), 人工心肺時間（オッズ比 $1.01 ， 95 \%$ 信頼区間 1.00-1.02, $p=0.013 ）$ が PND の有意な危険因子としてあげられた (Table 3). TND の発生に打いては, 単変量解析では, atherothrombotic aorta, Severe WMC, 頸動脈狭窄が有意 な危険因子としてあげられ, 多変量解析では, atherothrombotic aorta（オッズ比 4.05，95\% 信頼区間 1.45-10.6, $p=0.009$ ), Severe WMC (オッズ比 $3.87,95 \%$ 信頼区間 $1.68-9.15, p=0.002$ ), 頸動脈狭窄（オッズ比 $2.70,95 \%$ 信頼区間 1.03-6.66, $p=0.035 ）$ が TND 発生の有意な危険 因子としてあげられた。

観察期間中に 97 例の遠隔死亡を認め，そのうち 35 例が 心臟大血管あるいは脳血管関連死亡であった. 5 年生存率 は WMCの重症度と相関して有意に減少し（Mild： $87.6 \pm 3.5 \%$, Moderate $77.8 \pm 3.9 \%$, Severe $62.6 \pm 5.7 \%$, Log-rank trend $p=0.020 ） （$ Fig. $2 \mathrm{~A}$ ），心大血管 ·脳血管関 連死亡回避率も WMC の重症度と相関して有意に低下し た (Mild:92.3 $\pm 2.9 \%$, Moderate 89.3 $\pm 3.0 \%$, Severe $83.8 \pm 4.3 \%$, Log-rank trend $p<0.001$ ) (Fig. $2 \mathrm{~B}$ ).

術後 1 年以内の脳梗塞の発生は 11 例 (3.7\%) に認めら れ，WMC 重症度は術後脳梗塞発生の有意な危険因子とは ならなかった (Mild:4.4\%, Moderate 2.9\%, Severe 4.2\%, $p=0.815)$. 
Table 1 Patient characteristics

\begin{tabular}{|c|c|c|c|c|c|}
\hline Variables & $\begin{array}{l}\text { Overall } \\
(n=359)\end{array}$ & $\begin{array}{l}\text { WMC Mild } \\
\quad(n=100)\end{array}$ & $\begin{array}{l}\text { WMC Moderate } \\
\qquad(n=158)\end{array}$ & $\begin{array}{l}\text { WMC Severe } \\
\quad(n=101)\end{array}$ & $\begin{array}{l}p \text {-Value } \\
\text { (trend) }\end{array}$ \\
\hline Age (years) & $72.5 \pm 9.7$ & $66.6 \pm 13.4$ & $74.0 \pm 6.4$ & $76.1 \pm 6.8$ & $<0.001^{*}$ \\
\hline Female & $85(23.7)$ & $21(21.0)$ & $32(20.3)$ & $32(31.7)$ & 0.074 \\
\hline BMI $\left(\mathrm{kg} / \mathrm{m}^{2}\right)$ & $23.4 \pm 3.2$ & $24.0 \pm 3.5$ & $23.4 \pm 3.1$ & $22.9 \pm 3.1$ & $0.006^{*}$ \\
\hline Hypertension & $316(88.0)$ & $87 \quad(87.0)$ & $138(87.3)$ & $91 \quad(90.1)$ & 0.498 \\
\hline Dyslipidemia & $142(39.6)$ & $41 \quad(41.0)$ & $59(37.3)$ & $42(41.6)$ & 0.931 \\
\hline Diabetes mellitus & $55(15.3)$ & $18(18.0)$ & $24(15.2)$ & $13(12.9)$ & 0.313 \\
\hline Smoking & $263(73.9)$ & $70(70.0)$ & $119(76.8)$ & $74 \quad(73.3)$ & 0.601 \\
\hline Chronic dissection & $63(17.6)$ & $24 \quad(24.0)$ & $25(15.8)$ & $14(13.9)$ & 0.059 \\
\hline Previous aortic surgery & $77 \quad(21.5)$ & $23(23.0)$ & $33(20.1)$ & $21(20.8)$ & 0.704 \\
\hline Preoperative AF & $32(8.9)$ & $5(5.0)$ & $17(10.8)$ & $10(9.9)$ & 0.224 \\
\hline Chronic lung disease & $117(32.6)$ & $33(33.0)$ & $46(29.1)$ & $38(37.6)$ & 0.482 \\
\hline eGFR $\left(\mathrm{ml} / \mathrm{min} / 1.73 \mathrm{~m}^{2}\right)$ & $55.6 \pm 20.5$ & $63.8 \pm 20.3$ & $54.5 \pm 20.6$ & $49.1 \pm 17.6$ & $<0.001^{*}$ \\
\hline Atherothrombotic aorta & $38(11.4)$ & $7(7.3)$ & $22(15.1)$ & $9(9.4)$ & 0.648 \\
\hline Ischemic heart disease & $124(34.5)$ & $21(21.0)$ & $59(37.3)$ & $44(43.6)$ & $<0.001^{*}$ \\
\hline Carotid artery stenosis & $48(13.4)$ & $7(7.0)$ & $22(13.9)$ & $19(18.8)$ & $0.014^{*}$ \\
\hline Intracranial artery stenosis & $33(9.2)$ & $8(8.0)$ & $11(7.0)$ & $14(13.9)$ & 0.149 \\
\hline Incomplete circle of Willis & $108(30.1)$ & $32(32.0)$ & $51(32.3)$ & $25(24.8)$ & 0.262 \\
\hline Neurological dysfunction & $15(4.2)$ & $2(2.0)$ & $3(1.9)$ & $10(9.9)$ & $0.005^{*}$ \\
\hline Previous stroke & $113(31.5)$ & $12(12.0)$ & $52(32.9)$ & $49(48.5)$ & $<0.001^{*}$ \\
\hline EuroSCORE II $(\%)$ & $4.9 \pm 4.1$ & $3.6 \pm 2.6$ & $5.1 \pm 4.4$ & $5.9 \pm 4.4$ & $<0.001^{*}$ \\
\hline Japan score (30-day mortality, \%) & $6.4 \pm 5.5$ & $5.0 \pm 3.8$ & $6.4 \pm 5.1$ & $7.8 \pm 7.0$ & $<0.001^{*}$ \\
\hline Japan score (30-day mortality + complications, \%) & $25.4 \pm 12.4$ & $21.9 \pm 10.3$ & $25.5 \pm 12.3$ & $28.5 \pm 13.6$ & $<0.001^{*}$ \\
\hline
\end{tabular}

$\mathrm{BMI}$, body mass index; $\mathrm{AF}$, atrial fibrillation ; $\mathrm{eGFR}$, estimated glomerular filtration rate.

Table 2 Operative data and postoperative complications

\begin{tabular}{|c|c|c|c|c|c|}
\hline Variables & $\begin{array}{l}\text { Overall } \\
(n=359)\end{array}$ & $\begin{array}{l}\text { WMC Mild } \\
\quad(n=100)\end{array}$ & $\begin{array}{l}\text { WMC Moderate } \\
\qquad(n=158)\end{array}$ & $\begin{array}{l}\text { WMC Severe } \\
\qquad(n=101)\end{array}$ & $\begin{array}{l}p \text {-Value } \\
\text { (trend) }\end{array}$ \\
\hline $\mathrm{CPB}$ time $(\min )$ & $178.4 \pm 57.1$ & $179.4 \pm 59.5$ & $170.9 \pm 43.1$ & $189.2 \pm 71.0$ & 0.254 \\
\hline Myocardial ischemia (min) & $79.8 \pm 39.0$ & $83.5 \pm 52.7$ & $75.7 \pm 30.9$ & $82.7 \pm 33.7$ & 0.085 \\
\hline Minimum tympanic temperature $\left({ }^{\circ} \mathrm{C}\right)$ & $21.4 \pm 1.8$ & $21.7 \pm 1.8$ & $21.5 \pm 1.8$ & $21.1 \pm 1.6$ & $0.002^{*}$ \\
\hline Minimum rectal temperature $\left({ }^{\circ} \mathrm{C}\right)$ & $26.1 \pm 2.1$ & $26.1 \pm 2.0$ & $26.1 \pm 2.1$ & $26.2 \pm 2.2$ & 0.170 \\
\hline ACP time $(\min )$ & $95.9 \pm 28.9$ & $90.4 \pm 24.0$ & $96.6 \pm 29.0$ & $100.4 \pm 32.3$ & $0.002^{*}$ \\
\hline Circulatory arrest of lower body (min) & $39.8 \pm 14.2$ & $38.9 \pm 13.9$ & $39.3 \pm 13.6$ & $41.5 \pm 15.5$ & 0.774 \\
\hline Concomitant $\mathrm{CABG}$ & $109(30.4)$ & $29(29.0)$ & $47(29.8)$ & $33(32.7)$ & 0.571 \\
\hline Elephant trunk insertion & $74(20.6)$ & $23(23.0)$ & $28(17.7)$ & $23(22.8)$ & 0.767 \\
\hline 30-day mortality & $5(1.4)$ & $2(2.0)$ & $1(0.63)$ & $2(2.0)$ & 0.993 \\
\hline Hospital mortality & $10(2.8)$ & $4(4.0)$ & $3(1.9)$ & $3(3.0)$ & 0.660 \\
\hline 1-year mortality & $27(7.9)$ & $5(5.1)$ & $8(5.4)$ & $14(14.7)$ & $0.014^{*}$ \\
\hline Permanent neurologic deficits & $8(2.2)$ & $0(0)$ & $2(1.3)$ & $6(5.9)$ & $0.004^{*}$ \\
\hline Transient neurologic deficits & $28(7.8)$ & $4(4.0)$ & $9(5.7)$ & $15(14.9)$ & $0.004^{*}$ \\
\hline Deep sternal wound infection & $6(1.7)$ & $3(3.0)$ & $2(1.3)$ & $1(1.0)$ & 0.267 \\
\hline Postoperative AF & $112(31.2)$ & $24(24.0)$ & $50(31.7)$ & $38(37.6)$ & $0.037^{*}$ \\
\hline Pneumonia & $23(6.4)$ & $5(5.0)$ & $7(4.4)$ & $11(10.9)$ & 0.090 \\
\hline Hoarseness & $59(16.4)$ & $19(19.0)$ & $23(14.6)$ & $17(16.8)$ & 0.680 \\
\hline Prolonged ventilation $(>48 \mathrm{~h})$ & $41(11.5)$ & $10(10.0)$ & $17(10.8)$ & $14(14.7)$ & 0.374 \\
\hline Tracheostomy & $20(5.6)$ & $6(6.0)$ & $8(5.1)$ & $6(5.9)$ & 0.986 \\
\hline Renal failure & $18(5.0)$ & $4(4.0)$ & $6(3.8)$ & $8(7.9)$ & 0.202 \\
\hline Length of hospital stay (days) & $21.0(16.0-29.0)$ & $20.0(15.0-26.3)$ & $21.0(16.0-28.0)$ & $22.0(17.0-32.0)$ & 0.509 \\
\hline Discharge to home & $305(87.4)$ & $86(89.6)$ & $136(87.7)$ & $83(84.7)$ & 0.304 \\
\hline
\end{tabular}

$\mathrm{CPB}$, cardiopulmonary bypass; $\mathrm{ACP}$, antegrade selective cerebral perfusion; $\mathrm{CABG}$, coronary artery bypass grafting; $\mathrm{AF}$, atrial fibrillation. 
Table 3 Univariate and multivariate analysis of PNDs

\begin{tabular}{|c|c|c|c|c|c|c|}
\hline \multirow{2}{*}{ Variables } & \multicolumn{3}{|c|}{ Univariate } & \multicolumn{3}{|c|}{ Multivariate } \\
\hline & OR & $95 \% \mathrm{CI}$ & $p$-Value & OR & $95 \% \mathrm{CI}$ & $p$-Value \\
\hline Age (years) & 1.03 & $0.96-1.14$ & 0.484 & & & \\
\hline Female & 1.97 & $0.46-8.41$ & 0.377 & & & \\
\hline Hypertension & - & - & 0.151 & & & \\
\hline Dyslipidemia & 1.54 & $0.38-6.27$ & 0.546 & & & \\
\hline Diabetes mellitus & 3.45 & $0.80-14.9$ & 0.121 & & & \\
\hline Smoking & 0.58 & $0.14-2.48$ & 0.476 & & & \\
\hline Chronic dissection & 0 & - & 0.077 & & & \\
\hline Previous aortic surgery & 0.51 & $0.06-4.23$ & 0.508 & & & \\
\hline Preoperative AF & 3.57 & $0.69-18.5$ & 0.174 & & & \\
\hline Chronic lung disease & 0.29 & $0.04-2.38$ & 0.184 & & & \\
\hline eGFR $\left(\mathrm{ml} / \mathrm{min} / 1.73 \mathrm{~m}^{2}\right)$ & 0.97 & $0.94-1.00$ & 0.087 & & & \\
\hline Atherothrombotic aorta & 5.42 & $1.24-23.6$ & $0.042^{*}$ & 7.56 & $1.37-38.6$ & $0.023^{*}$ \\
\hline Ischemic heart disease & 1.14 & $0.27-4.85$ & 0.860 & & & \\
\hline Severe white matter change & 6.93 & $1.38-34.9$ & $0.010^{*}$ & 7.56 & $1.54-55.6$ & $0.012^{*}$ \\
\hline Carotid artery stenosis & 0.92 & $0.11-7.68$ & 0.941 & & & \\
\hline Intracranial artery stenosis & 1.42 & $0.17-11.9$ & 0.755 & & & \\
\hline Incomplete circle of Willis & 1.30 & $0.29-8.95$ & 0.747 & & & \\
\hline Neurological dysfunction & 3.44 & $0.40-29.9$ & 0.329 & & & \\
\hline Previous stroke & 2.22 & $0.55-9.04$ & 0.271 & & & \\
\hline CPB time $(\min )$ & 1.01 & $1.00-1.02$ & $0.004^{*}$ & 1.01 & $1.00-1.02$ & $0.013^{*}$ \\
\hline Minimum tympanic temperature $\left({ }^{\circ} \mathrm{C}\right)$ & 0.94 & $0.64-1.36$ & 0.755 & & & \\
\hline ACP time $(\min )$ & 0.99 & $0.97-1.02$ & 0.662 & & & \\
\hline Lower body circulatory arrest（min） & 1.04 & $0.98-1.09$ & 0.180 & & & \\
\hline Concomitant CABG & 1.39 & $0.33-5.91$ & 0.663 & & & \\
\hline
\end{tabular}

PNDs, permanent neurological deficits ; OR, odds ratio ; CI, confidence interval ; AF, atrial fibrillation ; eGFR, estimated glomerular filtration rate; $\mathrm{CPB}$, cardiopulmonary bypass; $\mathrm{ACP}$, antegrade selective cerebral perfusion ; CABG, coronary artery bypass grafting.

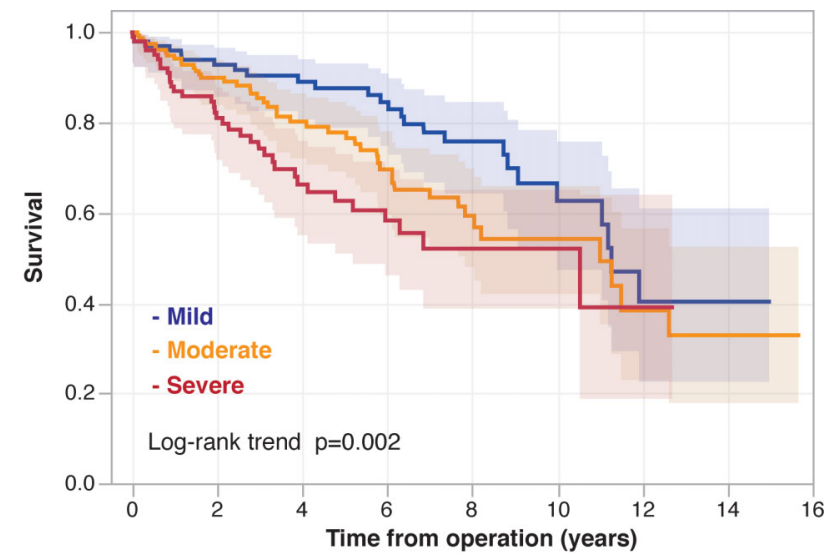

Number at risk

$\begin{array}{lcccccccc}\text { Mild: } & 100 & 84 & 64 & 55 & 31 & 17 & 6 & 3 \\ \text { Moderate: } & 158 & 115 & 71 & 49 & 24 & 18 & 8 & 5 \\ \text { Severe: } & 101 & 67 & 40 & 27 & 12 & 6 & 3 & \end{array}$

\section{( A )}

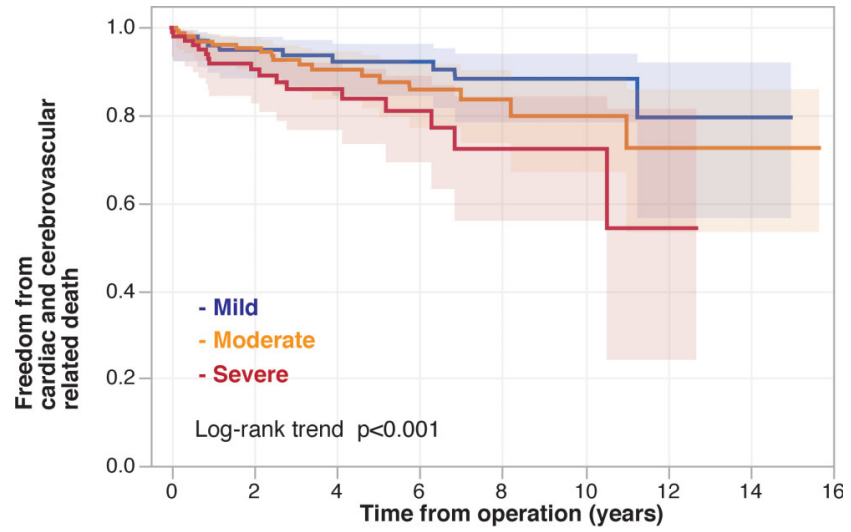

Number at risk

$\begin{array}{lcccccccc}\text { Mild: } & 100 & 84 & 64 & 55 & 31 & 17 & 6 & 3 \\ \text { Moderate: } & 158 & 115 & 71 & 49 & 24 & 18 & 8 & 5 \\ \text { Severe: } & 101 & 67 & 40 & 27 & 12 & 6 & 3 & \end{array}$

( B )

Fig. 2

Kaplan-Meier survival curve. Overall survival for the 3 groups (A) and freedom from cardiac- and cerebrovascular-related death (B).

\section{考察}

高齢者に対する手術件数の著しい増加に伴い，特に待機 手術に打いては弓部全置換術の術前評価の必要性はより重 要なものとなった。当科でもこれまでに，慢性腎藏病5),
慢性閉塞性肺疾患 ${ }^{6}$ といった術前併存疾患だけでなく，サ

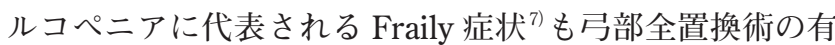
意な危険因子として報告してきた。特に高齢者に扔いて は，直接的に院内死亡率や遠隔死亡率に関連し，介護をめ ぐる医療費の増大の問題もあり, PNDの発生は最も重大 
Table 4 Univariate and multivariate analysis of TNDs

\begin{tabular}{|c|c|c|c|c|c|c|}
\hline \multirow{2}{*}{ Variables } & \multicolumn{3}{|c|}{ Univariate } & \multicolumn{3}{|c|}{ Multivariate } \\
\hline & OR & $95 \% \mathrm{CI}$ & $p$-Value & OR & $95 \% \mathrm{CI}$ & $p$-Value \\
\hline Age (years) & 1.03 & $0.99-1.09$ & 0.186 & & & \\
\hline Female & 1.32 & $0.56-3.11$ & 0.534 & & & \\
\hline Hypertension & 0.60 & $0.21-1.66$ & 0.345 & & & \\
\hline Dyslipidemia & 1.16 & $0.53-2.53$ & 0.711 & & & \\
\hline Diabetes mellitus & 0.40 & $0.09-1.75$ & 0.172 & & & \\
\hline Smoking & 0.52 & $0.23-1.14$ & 0.112 & & & \\
\hline Chronic dissection & 1.31 & $0.51-3.38$ & 0.583 & & & \\
\hline Previous aortic surgery & 0.78 & $0.29-2.13$ & 0.623 & & & \\
\hline Preoperative AF & 1.25 & $0.36-4.39$ & 0.734 & & & \\
\hline Chronic lung disease & 0.98 & $0.43-2.23$ & 0.958 & & & \\
\hline eGFR $\left(\mathrm{ml} / \mathrm{min} / 1.73 \mathrm{~m}^{2}\right)$ & 0.99 & $0.97-1.01$ & 0.162 & & & \\
\hline Atherothrombotic aorta & 4.01 & $1.63-9.89$ & $0.005^{*}$ & 4.05 & $1.45^{-10.6}$ & $0.009 *$ \\
\hline Ischemic heart disease & 1.25 & $0.57-2.76$ & 0.586 & & & \\
\hline Severe white matter change & 3.29 & $1.50-7.19$ & $0.003^{*}$ & 3.87 & $1.68-9.15$ & $0.002 *$ \\
\hline Carotid artery stenosis & 3.55 & $1.50-8.39$ & $0.007^{*}$ & 2.70 & $1.03-6.66$ & $0.035^{*}$ \\
\hline Intracranial artery stenosis & 2.35 & $0.83-6.67$ & 0.134 & & & \\
\hline Incomplete circle of Willis & 1.56 & $0.71-3.45$ & 0.280 & & & \\
\hline Neurological dysfunction & 0.84 & $0.11-6.62$ & 0.864 & & & \\
\hline Previous stroke & 1.71 & $0.78-3.74$ & 0.187 & & & \\
\hline CPB time $(\min )$ & 1.01 & $1.00-1.01$ & 0.083 & & & \\
\hline Minimum tympanic temperature $\left({ }^{\circ} \mathrm{C}\right)$ & 1.00 & $0.80-1.24$ & 0.978 & & & \\
\hline ACP time $(\mathrm{min})$ & 1.00 & $0.99-1.01$ & 0.835 & & & \\
\hline Lower body circulatory arrest (min) & 0.99 & $0.96-1.01$ & 0.278 & & & \\
\hline Concomitant CABG & 1.09 & $0.48-2.50$ & 0.832 & & & \\
\hline
\end{tabular}

TNDs, transient neurological deficits; $\mathrm{OR}$, odds ratio; $\mathrm{CI}$, confidence interval; $\mathrm{AF}$, atrial fibrillation; eGFR, estimated glomerular filtration rate; $\mathrm{CPB}$, cardiopulmonary bypass; $\mathrm{ACP}$, antegrade selective cerebral perfusion ; $\mathrm{CABG}$, coronary artery bypass grafting.

な合併症と考えられている.

今回の検討では，われわれは Fazekas スケールを用い たが，心臟血管外科医と放射線科医による画像評価解析血 管の有意な相関は，術前評価における高い汎用性を示唆し ている. WMCの重症度が PND や TND といった神経学 的合併症の有意な危険因子となることが示されたが，Severe WMC 群では，加齢性变化を反映して，有意に高齢で より多くの併存疾患を抱えた患者が含まれていた。しか し, 早期死亡率は 3 群間で同等であり, 多変量ロジスティ ック解析より Severe WMC が有意な PND と TND の危険 因子となったことより，WMC が順行性脳灌流を用いた低 体温循環停止手術に対して重要な意味を持つことが示唆さ れた。順行性脳灌流時間や最低鼓膜温度が 3 群間で有意に 異なったが，いずれも PND，TND の有意な危険因子とし てはあげられなかった。長期成績の観点からも，WMC は 心大血管・脳血管関連死亡を含む遠隔死亡の有意な危険因 子としてあげられ，年齢そのものよりもより重要な意味合 いを持つことが推察される。

ステントグラフト内挿術やハイブリッド治療がハイリス ク症例に対する代替療法として用いられているが，これら の治療法での周術期脳合併症の発生はけっして低いとは言
えず8), 今回の結果からも, Mild あるいは Moderate WMC に対する弓部置換術はいぜんとして gold standard な治療法であると言えるであろう。しかしながら, Severe WMC に対しては，これらの治療法の人工心肺や循環停止 を用いないというメリットが，手術成績の向上に寄与する ことが期待される.

\section{結語}

術前 MRI 評価により Fazekas スケールで定義される WMC 重症度は，順行性脳灌流法を用いた弓部置換術術後 神経学的合併症の発生に有意に寄与し，心大血管・脳血管 関連死亡を含む中期・遠隔期死亡の有意な危険因子として あげられた。 WMC は弓部置換術前の重要な評価項目の 1 つとして考慮すべきである。

\section{文献}

1) Shibata $M$, Ohtani $R$, Ihara $M$ et al. White matter lesions and glial activation in a novel mouse model of chronic cerebral hypoperfusion. Stroke $2004 ; 35: 2598-603$.

2) Van Der Flier WM, van Straaten EC, Barkhof F et al. Small vessel disease and general cognitive function in nondisabled elderly. Stroke $2005 ; 36: 2116-20$.

3) Inzitari D, Pracucci G, Poggesi A et al. Changes in white 
matter as determinant of global functional decline in older independent outpatients : three year follow-up of ladis (leukoaraiosis and disability) study cohort. BMJ 2009; 339 : b2477.

4) Fazekas F, Chawluk JB, Alavi A et al. Mr signal abnormalities at $1.5 \mathrm{t}$ in alzheimer's dementia and normal aging. Am J Roentgenol $1987 ; 149$ : 351-6.

5) Okada K, Omura A, Kano H et al. Outcome of elective total aortic arch replacement in patients with non-dialysisdependent renal insufficiency stratified by estimated glomerular filtration rate. J Thorac Cardiovasc Surg 2014 ; 147 : 96672.

6) Miyahara $\mathrm{S}$, Nakai $\mathrm{H}$, Izawa $\mathrm{N}$ et al. Influences of chronic obstructive pulmonary disease on outcomes of total arch replacement. Ann Thorac Surg 2015 ; 99 : 72-8.

7) Ikeno $\mathrm{Y}$, Koide $\mathrm{Y}$, Abe $\mathrm{N}$ et al. Impact of sarcopenia on the outcomes of elective total arch replacement in the elderly. Eur J Cardiothorac Surg 2017 ; 51 : 1135-41.

8) Hiraoka A, Chikazawa G, Totsugawa T et al. Objective analysis of midterm outcomes of conventional and hybrid aortic arch repair by propensity-score matching. J Thorac Cardiovasc Surg 2017 ; 154 : 100-6.

\section{[質疑応答］}

齋藤佳克先生（東北大学大学院）：弓部置換術の対象患 者群に打ける予後の観点から, 大脳白質病変の意義の大き さを検討した有意義な後方視的臨床研究と思います。この ような大脳白質病変の意義を急性期神経学的評価に加えて 長期予後に関して検討できるのは，神戸大学における弓部 置換術の豊富な症例数と優れた手術成績が背景にあること は言を俟ちません，多岐にわたる検討ではありますが，こ こでは質問を以下の 3 つに集約します。

質問 1 ：大脳白質病変の程度と予後に関して，過去の報 告では, Mild と Moderate レベルでは臨床経過にほとんど 差がなく, Severe の場合にだけ有意に予後が悪化してい ます。午の傾向は発表者らの解析でも再現されています。 したがって，3 群分割比較より，2 群分割比較がより重要 であり，それを行うための大脳白質病変評価における重要 な閾值の同定と，その閾值を超えた場合の脳神経障害が発 生する機序の考察，それを検討するための術前後での MRI 所見の変化を評価し記述する必要があるものと考え られますが，どのように検討されておられますか？

質問 2 : Severe な大脳白質病変がある患者群で長期生命 予後が悪いのは, 術前の動脈硬化病変が強いからであると 類推されるため，この患者要因は外科医が長期予後を修飾 できない因子になるかと思います。手術成績を改善するた めに選択的脳分離体外循環の短縮も考察されているようで すが，PNDのリスクファクターとして多変量解析で抽出 されたのは，選択的脳分離体外循環ではなく，体外循環時 間でした。皇の点に関する考察はいかがでしょうか？

質問 3 : PND と TND に関するリスクファクターとして
Severe WMC の存在が抽出されています。検討された 3 群 間で同一の選択的脳分離体外循環方法でなされたことによ って，今回の結果がもたらされたとした場合，選択的脳分 離体外循環の回路構成，モニタリング方法，リアルタイム のモニタリング結果による循環管理改善のための介入につ いて，より深い考察が必要に思われますが，いかがでしょ うか?

\section{池野友基先生（神戸大学）}

回答 1 : 当科の過去の報告 (Morimoto $\mathrm{N}$, et al. Ann Thorac Surg 2009 ; 88 : 476-81.) では, TND 発生の cutoff が Moderate 以上の大脳白質病変とあり, 先生からもご指 摘がありましたとおり，臨床的な経験より，われわれは Severe 以上の大脳白質病変が術後脳神経病害の発生に寄 与するのではないかという仮説を持っておりましたので, 3 群に分けての検討を行いました。

また，後方視的研究の 1 つの limitation として，神経学 的合併症が発生しなかった群での術後 MRI がないという ことがあげられます。今後の課題としていければと存じま す.

回答 2 : ご指摘のとおり, 術前の動脈硬化病変は外科医 が修飾できない因子と考えます。しかし，危険因子として 認識することで初めて, 待機手術においては手術時期の検 討，術式の選択，ひいては手術自体を行うかどうかという ことについて患者-家族を含めた議論ができるのではない かと考えています，今回の検討を benchmark として，Severe な大脳白質病変を持つ患者に対するより有用な術式 の検討ができればと考えています。

脳分離体外循環時間は今回の検討では神経学的合併症発 生の危険因子となりませんでしたが，今回のコホートでは 全例で同様の術式を用いているために，脳分離体外循環時 間の分散が非常に狭い範囲に限られていることが 1 つの要 因と考えられます。われわれの臨床的感覚では，やはり有 意な危険因子として考慮すべきであるという仮説より，脳 分離体外循環時間を軽減できる術式を検討したしだいで す。また，PNDの危険因子として体外循環時間があげら れましたが，併施手術は危険因子となっていないことを考 慮しますと，末梢吻合側からの出血であったり，体外循環 を離脱できない場合であったりといった背景がバイアスと して考察されます。

回答 3 : 非常に難しい質問です．脳保護作用の報告され ている薬剤を投与する，灌流量を増やす，灌流圧をあげ る，より低体温での循環停止を行うなどの対応が考えられ ますが，それぞれの方法については，cutoff 值も含め今後 の検討が待たれるのが現況と考えます。 